\title{
JCK MEMS / NEMS 2011 (The 2nd Japan-China-Korea Joint Conference on MEMS / NEMS for Green \& Life Innovation and Industrial Convergence) 報告
}

\author{
内藤 皓貴（技術研究組合 BEANS 研究所）
}

\section{1. はじめに}

国際会議 JCK MEMS / NEMS (The Japan-China-Korea Joint Conference on MEMS / NEMS for Green \& Innovation and Industrial Convergence）は，日本・中国・ 韓国において, MEMS / NEMS 分野の, 特にグリーンイノ ベーションおよびライフイノベーションにかかわる研究者 やマネージャーが，最新の技術動向や開発戦略を発表し， 交流することを目的として開催された国際会議である。 2010 年に札幌で第 1 回目が開催され，2011 年の 9 月 5 日 から 7 日まで，その第 2 回目として韓国の済州島で JCK MEMS / NEMS 2011 が開催された。

開催地についても簡単に紹介すると，済州島は東シナ海 に位置する韓国最南端の火山島であり，その一帯が「済州 の火山島と溶岩洞窟」としてユネスコの世界遺産に登録さ れている美しい島である。その美しい景色もさることなが ら，済州島は韓国の特別自治道に制定されており，中国を 含む多くの国から査証なしに入国することができることも あって, 今回, 開催地として選ばれたとのことであった。

\section{2. 会議の概要}

前章において本国際会議について簡単に説明させていた だいたが，もともとは個々の研究者単位における交流に端 を発していることもあり，会議はアットホームな䨌囲気の 中，自由闊達な議論が行われた。

今回の発表件数は全体で 46 件あり，その内訳は，招待講 演 5 件，オーラル発表 23 件，ポスター発表 18 件であった。 地域別に発表件数をみると，日本 18 件，韓国 18 件，中国 10 件であり，各国から偏りなく発表が行われていた。開催 期間 3 日間中, 初日に 3 セッション，2 日目に 4 セッショ ン, 3 日目はテクニカルツアーが設けられた。

招待講演は，トップバッターとして東北大学の江刺正喜 教授から，「MEMS for practical applications by open collaboration」と題して, IT から安全, 環境, バイオと多 岐にわたる分野について MEMS の最新技術動向の紹介と, 現在, 東北大学において江刺教授主導で行われているマイ クロシステム融合研究開発センターの概要についての解説 が行われた。また, そのほかの招待講演としては, ソウル 大学（韓国） Prof. Kahp-Yang Suh から自然界に存在する 微細構造を応用した機能性デバイスや, 中国科学院（中国） Prof. Xinxin Li から MEMS の更なる低コスト化を狙った Single-side process, Bio-Nano-Informatics を融合した高 機能 NEMS の開発についてなど, 各国で行われている最新
の研究開発についての報告が行われた。

一般のオーラル，ポスターセッションでは，あえてセッ ションに技術分野ごとのカテゴリーを設けず，要素技術開 発から具体的なアプリケーションにまでおよぶ多様な発表 が連日行われた。全体の傾向としては，低コスト化やナノ 構造に関する発表が多く行われていた。また日本からは要 素技術（プロセス）に関する発表が多い一方で，中国や韓 国からは具体的なデバイスに関する発表が多いことが特徴 的であった（表 1 )。

\section{3. おわりに}

国際会議 JCK MEMS / NEMS は, 日中韓 3 か国におけ る研究者が交流を行い, 互いの最新技術動向を手軽に知る ことのできる格好の機会である。また，セッションによっ ては, 学生が主役となって発表, 質疑応答が行われる時間 帯もあり, 学生が国際会議一踏夕出す場としても好ましく 感じた。

次回は, 2012 年に中国上海近郊の周荘で開催が予定され ている。今後, JCK MEMS / NEMS において, 日中韓のさ らに多くの人々が交流・研鑽し合い，この地域における MEMS / NEMS がより一層発展していくことを期待する。

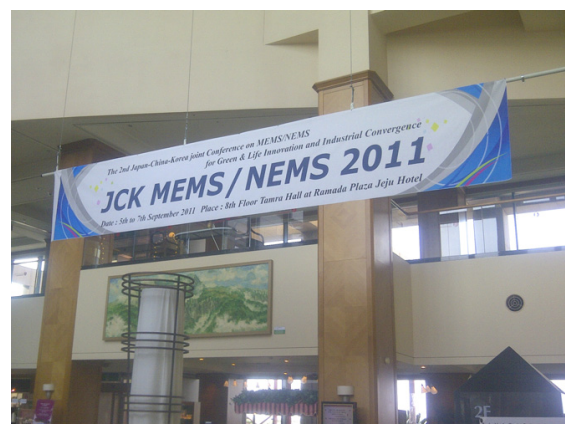

図 1 会場入口の国際会議掲示 (Ramada Plaza ホテル)

表 1 各国の発表分野内訳

\begin{tabular}{cccc} 
& 日本 & 中国 & 韓国 \\
\hline プロセス & $41 \%$ & $38 \%$ & $31 \%$ \\
材料 & $12 \%$ & $13 \%$ & $13 \%$ \\
デバイス & $29 \%$ & $50 \%$ & $44 \%$ \\
シミュレーション & $6 \%$ & - & $13 \%$ \\
その他(広報など) & $12 \%$ & - & - \\
※著者独自の分類、招待講演を除く & &
\end{tabular}

(平成 24 年 2 月 14 日受付) 